\title{
Assessment of paddy fields' damage caused by Cyclone Nargis using MODIS time-series images (2004-2013)
}

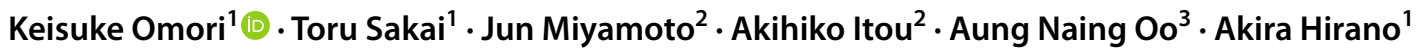

Received: 31 May 2020 / Revised: 22 September 2020 / Accepted: 7 October 2020 / Published online: 29 October 2020

(c) The Author(s) 2020

\begin{abstract}
The Ayeyarwady Delta in the Bay of Bengal, the rice bowl of Myanmar, depends on natural conditions, especially rainfall. During the dry season, the delta's coastal zone experiences saline water intrusion due to its low-lying topography. On May 2, 2008, Cyclone Nargis made landfall and crossed Ayeyarwady Region and Yangon City, affecting more than 50 townships and causing massive destruction of personal property and natural ecosystems. There is no doubt that Nargis caused an unprecedented large-scale disaster, but there is no objective method to quantify crop yield and salinity damage in the delta post-Nargis. The purpose of this study, therefore, is to clarify the changes in vegetation in paddy fields in the Ayeyarwady Delta using Moderate Resolution Imaging Spectroradiometer data pre- and post-Nargis and determine whether this method can be applied to measure crop and salinity damage. The study used daily composite data at a 250-m resolution (MOD09GQ, collection 6) from 2004 to 2013 and calculated NDVI and salinity indices smoothed by locally weighted regression (Lowess). Based on the results of our studies, NDVI peak value in 2008 was lower by $19 \%$ compared to 2007 data, and that the NDVI peak values declined for three straight years since May 2008 when Nargis struck. However, salinity damage evaluation preand post-Nargis (using the salinity index equation) showed that soil electrical conductivity did not tend to move up in the post-Nargis dry season (2009), indicating that the decrease in NDVI values was not due to salinity damage.
\end{abstract}

Keywords Ayeyarwady delta $\cdot$ Cyclone Nargis $\cdot$ NDVI $\cdot$ MODIS $\cdot$ Salinity index

\section{Introduction}

Tropical cyclones, which include tropical storms, severe tropical depression, typhoons, hurricanes, and cyclones, threaten lives and property because of their high winds, associated storm surge, excessive rain and flooding. These cyclones have often caused widespread damage to paddy crops in the delta regions, which located in the coastal zones of the high vulnerability to natural disasters.

The Ayeyarwady delta of Bay of Bengal, the rice bowl of Myanmar, has a population of approximately 8 million in an area of $35,032 \mathrm{~km}^{2}$ (Driel and Nauta 2014). Three regions

Keisuke Omori

omorik@affrc.go.jp

1 Japan International Research Center for Agricultural Sciences, 1-1 Owashi, Tsukuba, Ibaraki 305-8686, Japan

2 Space Engineering Development Co., Ltd., EDC Bldg, 5-62-1, Nakano, Nakano-ku, Tokyo 164-0001, Japan

3 Yezin Agricultural University, Yezin, Nay Pyi Taw, Myanmar occupy the delta-Ayeyarwady, Yangon and Bago. A total of 2.89 million ha in the delta are favorable for rice cultivation, while some are prone to flooding in the monsoon (Ministry of Agriculture and Irrigation (MOAI) 2015).

A total of 11 severe tropical cyclones hit Myanmar over the last 60 years, only two of which made landfall in the Ayeyarwady delta region. On May 2, 2008, Cyclone Nargis crossed the Ayeyarwady regions and Yangon City, affecting more than 50 townships and causing massive destruction to personal property and natural ecosystems (Aung et al. 2011). Official death toll estimates exceed 146 thousand fatalities making it the seventh deadliest cyclone ever recorded worldwide. Damage estimates at over US $\$ 10$ billion made it the most damaging cyclone ever recorded in the Indian Ocean (Fritz et al. 2009).

Rice production in the delta increased significantly from 1976 to 1988 with the implementation of the Paddy Land Development Projects 1 and 2 supported by the World Bank and the Asian Development Bank. The construction of polders provided with embankments, sluice gates, and drainage systems protected the rice farms from seawater intrusion 
(Driel and Nauta 2014). However, the polders degraded and Cyclone Nargis damaged many of the polders, resulting in the uncontrolled entry of seawater and, thus reducing rice yield. Many of the damaged rice areas remain prone to seawater intrusion even in the monsoon season (MOAI 2015).

In contrast, according to the government census statistics, in the paddy-planted area and crop yield in the Ayeyarwady delta, there is no tendency to reduce the area and yield compared to the pre- and post-Cyclone Nargis. The reliability of the statistical data on rice production has been discussed by previous studies (e.g. Matsuda 2009). The previous studies were assumed that the official statistics sometimes had a bias towards achieving the high rice production target set by the government.

Several studies have been conducted on the crop damage and recovery assessment of Cyclone Nargis through the field survey, such as the literature reviews and farmer's interview; however, those studies were conducted 1-3 years after the disaster due to prevent the risk of field survey at the disaster area.

Remote sensing equipment observes a wide area at any one time and regularly observes the same location; therefore, remotely sensed data have recently been used to assess the impact of natural disasters, including cyclone. Satellite remote sensing helps in tracking changes in paddy ecosystem and can assess performance through changes in land use, primary productivity, and phenology (e.g., Kerr and Ostrovsky 2003). Remote sensing-based indices such as normalized difference vegetation index (NDVI) are sensitive to variability in biomass and nitrogen content of crop canopies, reflecting the amount of vegetation and the degree of vegetation vigor. The NDVI theoretically ranges from -1.0 to 1.0. Several vegetation indices have been used as indirect indicators for assessing and drawing a map of soil salinity distribution. Similarly, a number of researchers have developed different salinity indices to detect and map soil salinity such as normalized difference salinity index and salinity index (Allbed and Kumar 2013).

Many studies are performed in order to assess the vegetation and salinity damage after cyclone using satellite data analysis. For example, Konda et al. (2018) assessed vegetation damage due to Hudhud cyclone based on NDVI using the Landsat- 8 satellite image in the southeastern coastal area of India. Goto et al. (2015) evaluated salinity damage to crops due to typhoon 9918 based on NDVI using the Landsat-5 satellite image in Kumamoto Prefecture, south part of Japan. Although these studies using the Landsat satellite image have been just assessed the fractional vegetation or salinity damage at a certain time during pre- and post-cyclone, very few attempts have been made to continuously observe and assess how to recover from the damage of vegetation or salinity after cyclone. On the contrary, time-series satellite data of Moderate Resolution Imaging
Spectroradiometer (MODIS) sensor onboard earth observation satellites like Terra and Aqua are capable of synoptic viewing of inaccessible and protected areas for monitoring the land surface processes with high temporal resolution (Dutta et al. 2015).

There is no doubt that Cyclone Nargis landfall caused the unprecedented large-scale disaster; however, there is no objective evidence of the crop yield and salinity damage of the post-Nargis in the delta. Therefore, the purpose of this study is to clarify the change of vegetation in the paddy fields during pre- and post-Nargis in the delta using MODIS time-series images from 2004 to 2013. That is, our research results lead to one of the objective evidences of the crop and salinity damage caused by Cyclone Nargis.

\section{Materials and methods}

\section{Study area}

The study area, Labutta township, is in the lower part of Ayeyarwady delta. The area covers the fertile alluvial low land and stands $1.52 \mathrm{~m}$ and above the sea level. The total area of Labutta, 300,566 ha, is composed of 99,642 ha agricultural land, 111,544 ha forestland and 85,829 ha non-agricultural land (Seinn Seinn et al. 2015). The major river Ayeyarwady and other rivers Pathein, Ywe, and Pyamalow Rivers are crossing from south to north of Labutta (Fig. 1). The coastal zone of Labutta is crisscrossed by tidal rivers discharging into the Bay of Bengal. The river water is affected by seawater intrusion especially at the end of dry season, or just before the onset of pre-monsoon season. Seawater sometimes reaches as far as more than $100 \mathrm{~km}$ from the estuary (Japan International Cooperation Agency (JICA) 2011).

Rainfed rice in Labutta occupied $86 \%$ of the total agricultural land. Cropping pattern depends on natural condition, especially rainfall. Farmers start wet season cultivation at the beginning of rainy season (May-June) and harvest at the beginning of dry season (November-December) after drying paddy at the field. Farmers in irrigated area practice dry season paddy between December and April. And, the farmers who have farming land with high moisture contents usually cultivate beans such as black gram, green gram, and groundnuts (JICA 2011). Rice paddy yields in Labutta are slightly higher than the national average and, however, still low overall when compared to the region. Planning Department data show that the rice yield for the dry season crop was 4.89 tons $\mathrm{ha}^{-1}$ in 2014-2015, while the monsoon crop yield was 3.21 tons $\mathrm{ha}^{-1}$, slightly above the national average of 2.56 tons ha $^{-1}$ (Fee et al. 2017).

Annual riverine floods are most common in Labutta due to intense rainfall at the peak of monsoon. Weather observations over a 30-year period (1988-2017) (observed 


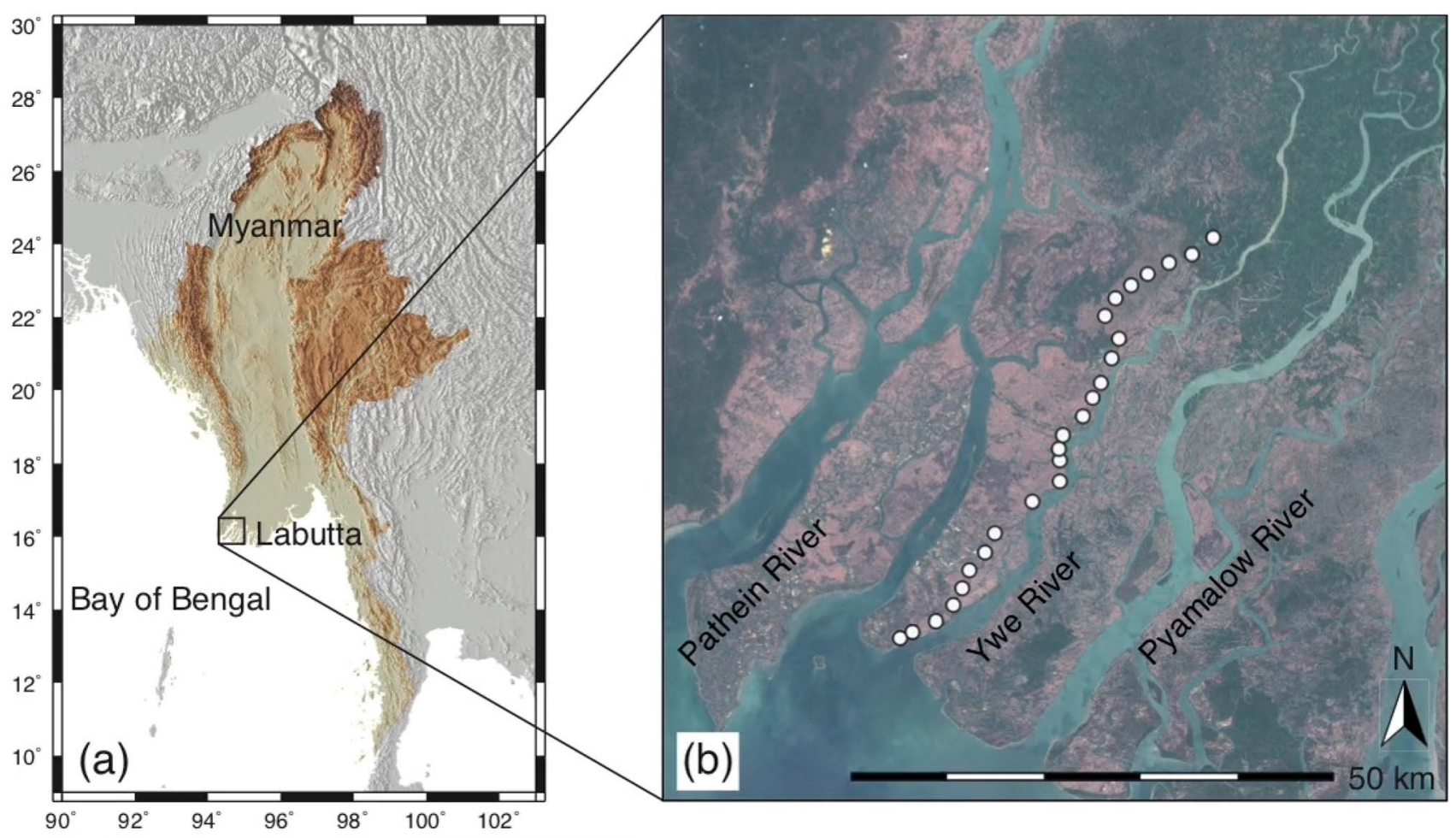

Fig. 1 Location of study area (a) and points of field sampling and satellite data analysis (b)

by Department of Agriculture (DOA), Labutta township, $16.1495780^{\circ} \mathrm{N}, 94.7575353^{\circ} \mathrm{E}$ ) showed an annual average rainfall of $3276 \mathrm{~mm}$, and the highest rainfall usually comes in from June to August; particularly, there were large fluctuations in monsoon season (Fig. 2). Monthly rainfall in
May 2008 was $871 \mathrm{~mm}$; this rainfall was $547 \mathrm{~mm}$ more than the average on May during 1988-2017. The annual mean temperature is $26.8^{\circ} \mathrm{C}$, the average maximum temperature is $32.3{ }^{\circ} \mathrm{C}$, and the average minimum temperature is $22.3{ }^{\circ} \mathrm{C}$ (Myanmar Environment Institute 2017).
Fig. 2 Average monthly rainfall in Labutta township during 1988-2017 and 2008 (separately)

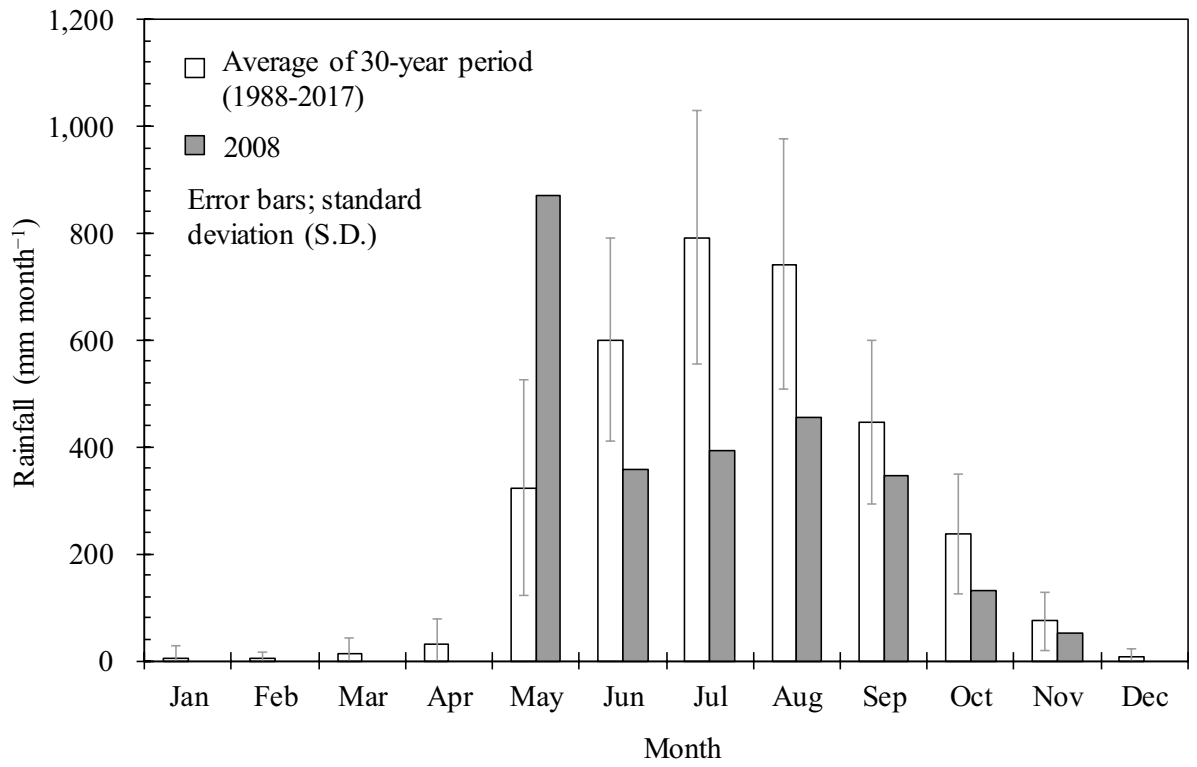




\section{Field sampling (ground-truth data)}

Soil sampling points were selected paddy fields along the Ywe river, from the river mouth to $65 \mathrm{~km}$ inland (Fig. 1b, monsoon crop area). A total of 25 soil samples were collected from the topsoil $(0-5 \mathrm{~cm})$ in the dry season (March 2017 and 2018) and rainy season (November 2016 and August and November 2018), respectively. The exact coordinates of each sampling point were registered using a global positioning system (GPS) with an accuracy of $\pm 5 \mathrm{~m}$. Each soil sample was comprised of four core subsamples that were collected at a distance of $20 \mathrm{~m}$ north, south, east, and west of the center sampling point (Allbed et al. 2014). Each sampling point was $0.4-6.5 \mathrm{~km}$ away from the river. Each sample was air-dried, ground, filtered with a 2-mm sieve, and stored in a plastic bag until analysis. The electrical conductivity (EC) of a 1:5 soil-water extract $\left(\mathrm{EC}_{1: 5}\right)$ was measured by handheld $\mathrm{EC}$ meter (ES-71, HORIBA). The $\mathrm{EC}_{1: 5}$ method has the advantage of simplicity reduced time and cost compared to saturation paste extracts $\left(\mathrm{EC}_{\mathrm{e}}\right)$ and a strong linear relationship between $\mathrm{EC}_{\mathrm{e}}$ and $\mathrm{EC}_{1: 5}$; however, they vary according to the area of interest. In Japan, the target of salt removal for paddy rice is often set to $\mathrm{EC}_{1: 5}$ of $0.3-0.7$ $\mathrm{dS} \mathrm{m}^{-1}$ (Crop Science Society of Japan 2012).

In order to compare with the MODIS NDVI time-series data and rice leaf greenness values, the soil plant analysis development (SPAD) values were measured at each soil sampling point, which is registered by GPS, using a SPAD502 plus chlorophyll meter (Konica Minolta) on July 28-30, 2018, in the monsoon season and November 28 to December 1,2018 , in the post-monsoon season. The field condition at the end of July was a few days to 35 days after transplanting or sowing, almost occupied the water area in the field, and from late November to early December was before harvest of monsoon crop; the conditions of the paddy fields differed depending on the distance from the river mouth. The uppermost expanded leaves on five consecutive plant hills were measured, and the five values were immediately averaged (Shibayama et al. 2012).

\section{Satellite data acquisition and data analysis}

The MODIS data were obtained from the U.S. Geological Survey (USGS) through the Earth Explorer tool (https:// earthexplorer.usgs.gov/). The NDVI satellite dataset used in this study was from the MODIS instrument onboard the Terra satellite. We used daily composite data at a $250-\mathrm{m}$ resolution (MOD09GQ, collection 6) from 2004 to 2013 (5 years before and after Cyclone Nargis landed in 2008, as an intermediate year). The one tile (h27v07, 10-20 $\mathrm{N} ; 91.3887-106.4266^{\circ} \mathrm{E}$ ) of MOD09GQ coverage for Labutta, the same soil sampling points registered by GPS, was accessed from the NASA Land Processes Distributed
Active Archive Center (https://e4ft101.cr.usgs.gov). The MOD09GQ vegetation product contains quality assessment (QA) data that contain information on the overall usefulness, the pixel reliability on a per-pixel basis. Furthermore, QA contains per-pixel quality flags relating to cloud state, cloud shadow, aerosol quantity, and basic land cover characteristics, such as the land/water, snow, and fire flags (Vermote et al. 2015). Our study extracted high-quality $(\mathrm{QA}=00)$ for 250-m resolution QA of data product quality, cloud state flags (bits $0-1$, clear or mixed), and land/water flags (bits $3-5$, land or shallow/deep inland water) for data product state QA flags.

The NDVI, which is a nonlinear combination of red and near-infrared (NIR) spectral radiances (NIR - red)/(NIR + red), exhibits a strong relationship with vegetation activity and green biomass. The index is usually employed for predicting vegetation phenology from space (Glenn et al. 2008; Hmimima et al. 2013; Karlsen et al. 2008). The NDVI time series were temporally smoothed by the locally weighted regression (Lowess) smoother as defined by Cleveland and Devlin (1988).

We have applied the three salinity indices (SI) proposed by Khan et al. (2005) and Douaoui et al. (2006) in Eqs. (1), (2) and (3), for soil salinity in this study to evaluate a relationship between $\mathrm{EC}_{1: 5}$ values measured on the ground and the SI values extracted from corresponding pixels.

SI1 $=\sqrt{B \times R}($ Khan et al. 2005)

SI $=\sqrt{G \times R}($ Khan et al. 2005)

SI3 $=\sqrt{G^{2} \times R^{2}}$ (Douaoui et al. 2006)

where $B, G$, and $R$ are expressed in reflectance in the blue, green, and red bands, respectively. Surface reflectance is the amount of light reflected by the surface of the earth; it is a ratio of surface radiance to surface irradiance, and as such is unitless, and typically has values from 0 to 1 . MOD09's surface reflectance values are scaled by 10,000 and then cast to 16-bit integers, so surface reflectance values in MOD09 files are typically from 0 to 10,000 (Vermote et al. 2015). In the case of SI, obtained SI was divided by 10,000 .

\section{Results}

\section{MODIS NDVI seasonal pattern}

Table 1 shows three-year (2007-2009) MODIS NDVI peak value and ratio of changes at survey points $(n=25)$. The peak value of MODIS NDVI from the river mouth to the point $23.3 \mathrm{~km}$ in 2008 decreased by $14.7-24.5 \%$ compared 
Table 1 Three-year (20072009) MODIS NDVI peak value and ratio of changes at survey points $(-=25)$

\begin{tabular}{|c|c|c|c|c|c|}
\hline \multirow{2}{*}{$\begin{array}{l}\text { Distance from the river } \\
\text { mouth }(\mathrm{km})\end{array}$} & \multicolumn{3}{|c|}{ NDVI peak (3 years) } & \multicolumn{2}{|l|}{ Changes (\%) } \\
\hline & 2007 & 2008 & 2009 & 2007 versus 2008 & 2007 versus 2009 \\
\hline 2.7 & 0.330 & 0.249 & 0.268 & -24.5 & -18.8 \\
\hline 5.4 & 0.598 & 0.458 & 0.482 & -23.4 & -19.4 \\
\hline 8.4 & 0.506 & 0.409 & 0.428 & -19.2 & -15.4 \\
\hline 10.2 & 0.453 & 0.382 & 0.411 & -15.7 & -9.3 \\
\hline 12.7 & 0.416 & 0.348 & 0.382 & -16.3 & -8.2 \\
\hline 15.6 & 0.478 & 0.383 & 0.433 & -19.9 & -9.4 \\
\hline 19.7 & 0.571 & 0.487 & 0.522 & -14.7 & -8.6 \\
\hline 23.3 & 0.541 & 0.444 & 0.492 & -17.9 & -9.1 \\
\hline 25.8 & 0.671 & 0.632 & 0.649 & -5.8 & -3.3 \\
\hline 28.6 & 0.703 & 0.692 & 0.690 & -1.6 & -1.8 \\
\hline 31.4 & 0.731 & 0.709 & 0.689 & -3.0 & -5.7 \\
\hline 32.8 & 0.674 & 0.647 & 0.633 & -4.0 & -6.1 \\
\hline 34.6 & 0.781 & 0.734 & 0.768 & -6.0 & -1.7 \\
\hline 37.3 & 0.700 & 0.674 & 0.683 & -3.7 & -2.4 \\
\hline 39.1 & 0.686 & 0.691 & 0.657 & 0.7 & -4.2 \\
\hline 40.9 & 0.725 & 0.698 & 0.708 & -3.7 & -2.3 \\
\hline 43.9 & 0.704 & 0.681 & 0.692 & -3.3 & -1.7 \\
\hline 46.2 & 0.780 & 0.729 & 0.751 & -6.5 & -3.7 \\
\hline 48.9 & 0.793 & 0.809 & 0.806 & 2.0 & 1.6 \\
\hline 51.3 & 0.790 & 0.788 & 0.794 & -0.3 & 0.5 \\
\hline 53.7 & 0.778 & 0.766 & 0.775 & -1.5 & -0.4 \\
\hline 56.2 & 0.790 & 0.765 & 0.781 & -3.2 & -1.1 \\
\hline 58.9 & 0.831 & 0.817 & 0.774 & -1.7 & -6.9 \\
\hline 62.1 & 0.798 & 0.781 & 0.791 & -2.1 & -0.9 \\
\hline 64.8 & 0.843 & 0.845 & 0.858 & 0.2 & 1.8 \\
\hline
\end{tabular}

to 2007 . On the other hand, at the point of $25.8 \mathrm{~km}$, which is the next point after $23.3 \mathrm{~km}$, the decreased ratio was $5.8 \%$. It was confirmed that the NDVI peak difference in 2008 was obviously different at the boundary of $23 \mathrm{~km}$. The MODIS NDVI time-series data (original) and the smoothed line by the Lowess smoother from 2004 to 2013 are shown in Fig. $3 a$ and $b$. These figures show from the Ywe river mouth to $23 \mathrm{~km}$ inland at the eight points average of MODIS NDVI (Fig. a), from 23 to $65 \mathrm{~km}$ inland at the 17 points average (Fig. b), respectively. During the rainy season from May to November, the number of usefulness MODIS data was much smaller than in the dry season due to the cloudy sky; however, the curve shown in the figures shows the timeseries change of NDVI from which noise has been removed by the Lowess smoother, and reproduced the rise of NDVI after rice planting and the peak time near the heading date. The maximum value in the NDVI seasonal change curve was used as the heading date; we estimated the peak date of NDVI value from 2004 to 2013 and calculated the change in NDVI values from 2008 to 2013, using 2007 as the base year (Table 2).

In Fig. 3a from the river mouth to $23 \mathrm{~km}$ inland, the NDVI peak appeared during October 5-26 every year; however, the peak in May 2008 appeared on November 2 (Table 2a). The peak after May 2008 has declined for 3 years when the cyclone Nargis attacked. Compared with 2007, the peak difference was $-19.0 \%$ in $2008,-12.3 \%$ in 2009 , and $-11.7 \%$ in 2010 . NDVI gradually recovered year by year, and almost recovered in 2011, showed the same NDVI as in 2007. In contrast, in Fig. $3 \mathrm{~b}$ from 23 to $65 \mathrm{~km}$ inland, the NDVI peak in 2008 was slightly lower than that of in 2007 , but the decreased ratio was not as high as in Fig. 3a; there has been no remarkable difference $(-2.6 \pm 2.3 \%)$ when the Cyclone Nargis attacked.

\section{Comparison of MODIS NDVI and measured SPAD}

As shown in Table 2, the NDVI peaks of (a) and (b) have a difference of 0.132-0.198 (excluding 2008), and the NDVI peaks of (b) are always high. Table 3 shows the relationship between the measured SPAD and MODIS NDVI analysis at the survey points. The satellite data at the time of the survey used MODIS NDVI average values for the 10 days from November 27 to December 6. The field survey at the end of July was a few days to 35 days after transplanting or sowing, and the survey from late November to early December 
Fig. 3 Time-series data of original and smoothed MODIS NDVI during 2004-2013, a $23 \mathrm{~km}$ inland from the river mouth and $\mathbf{b}$ from 23 to $65 \mathrm{~km}$ inland
Table 2 Peak date and its value of MODIS NDVI and ratio of changes
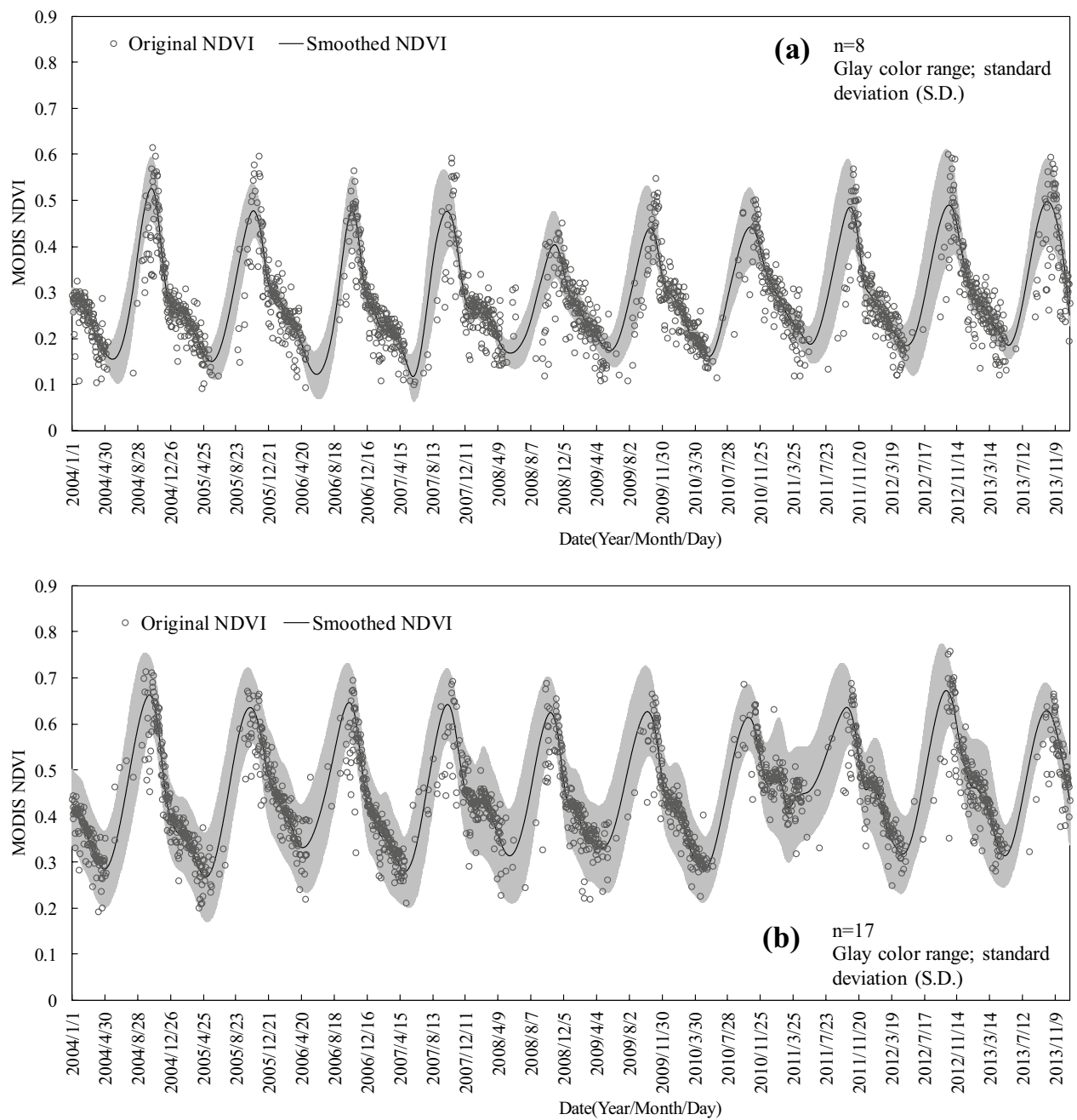

(a) From the river mouth to $23 \mathrm{~km}$ inland

\begin{tabular}{|c|c|c|c|c|c|c|}
\hline & \\
\hline Year & Peak value & NDVI peak & $\begin{array}{l}\text { Changes (\%) } \\
\text { (2007 as base) }\end{array}$ & Peak value & NDVI peak & $\begin{array}{l}\text { Changes (\%) } \\
\text { (2007 as base) }\end{array}$ \\
\hline 2004 & 17-Oct & 0.526 & & $10-$ Oct & 0.663 & \\
\hline 2005 & 26-Oct & 0.487 & & $14-O c t$ & 0.636 & \\
\hline 2006 & 23 -Oct & 0.486 & & 11 -Oct & 0.647 & \\
\hline 2007 & 5-Oct & 0.489 & 0.0 & 7-Oct & 0.642 & 0.0 \\
\hline 2008 & 2-Nov & 0.396 & -19.0 & 18-Oct & 0.625 & -2.6 \\
\hline 2009 & 18-Oct & 0.429 & -12.3 & 7-Oct & 0.627 & -2.3 \\
\hline 2010 & $20-$ Oct & 0.432 & -11.7 & $12-O c t$ & 0.614 & -4.4 \\
\hline 2011 & 20 -Oct & 0.487 & -0.4 & 7-Oct & 0.636 & -0.9 \\
\hline 2012 & 15-Oct & 0.490 & 0.2 & $5-\mathrm{Oct}$ & 0.672 & 4.7 \\
\hline 2013 & 10-Oct & 0.497 & 1.6 & 8-Oct & 0.629 & -2.0 \\
\hline
\end{tabular}

was before harvest. The condition of the paddy fields before harvesting was that $87 \%$ of the paddy fields were still growing from the river mouth to $34 \mathrm{~km}$ inland (Labutta town, $16.146667^{\circ} \mathrm{N}, 94.761111^{\circ} \mathrm{E}$ ) and $42 \%$ from Labutta town to $30 \mathrm{~km}$ inland.
Comparing measured SPAD and MODIS NDVI of the river mouth to $23 \mathrm{~km}$ inland (a) and $23 \mathrm{~km}$ to $65 \mathrm{~km}$ inland (b) in Table 3, MODIS NDVI of (b) was 0.14 higher than that of (a); it showed almost the same tendency as the difference between (a) and (b) in Table 2. In contrast, the 
Table 3 Relationship between measured SPAD and MODIS NDVI

\begin{tabular}{llll}
\hline & Survey date & Measured SPAD & MODIS NDVI \\
\hline (a) River mouth to 23 km inland & 29 Jul. 2018 & $28.9 \pm 3.4$ & $0.36 \pm 0.06$ \\
& 1 Dec. 2018 & $28.5 \pm 2.5$ & $0.41 \pm 0.04$ \\
Average & & $29.0 \pm 3.0$ & $0.39 \pm 0.05$ \\
(b) 23 km to 65 km inland & 28 \& 30 Jul. 2018 & $30.7 \pm 3.6$ & $0.52 \pm 0.09$ \\
& 28 \& 30 Nov. 2018 & $29.5 \pm 3.4$ & $0.53 \pm 0.07$ \\
Average & & $30.1 \pm 3.5$ & $0.53 \pm 0.08$ \\
(b)-(a) & & 1.1 & 0.14
\end{tabular}

Mean value \pm S.D

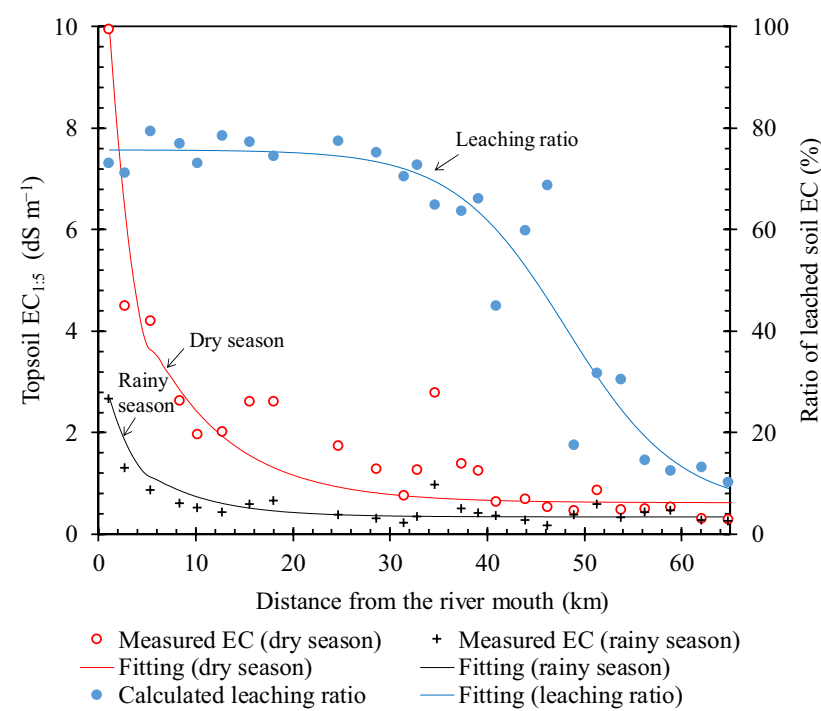

Fig. 4 Distribution of soil salinity $\left(\mathrm{EC}_{1: 5}\right)$ and the leaching ratio at distances from the river mouth in the rainy and dry seasons

difference of SPAD was 1.1, which was within the error range. Besides, no correlation was found between the measured SPAD value and MODIS NDVI $\left(R^{2}=0.02\right)$, and no significant difference was found $(p>0.05)$.

From the revealed results, it was confirmed that the difference in MODIS NDVI peak from the river mouth to $23 \mathrm{~km}$ shown in Fig. 3a and from 23 to $65 \mathrm{~km}$ shown in Fig. 3b was not related to SPAD. The data collected by MODIS range within $250 \mathrm{~m} \times 250 \mathrm{~m}$ plot. Therefore, it was suggested that the NDVI value becomes low at the measurement points near the estuary, due to the influence of the water area (sea or river) occupying more near the estuary.

\section{Salinization and desalinization range based on field sampling}

Figure 4 shows the distribution from the river mouth on soil salinity $\left(\mathrm{EC}_{1: 5}\right)$ in the rainy and dry seasons and the leaching ratio during the rainy season in the study area. The survey location is recorded by GPS and is measured at almost the same point each time. The leaching ratio was calculated using Eq. (4) on the average value of $\mathrm{EC}_{1: 5}$ on 2 years dry seasons (March 2017 and March 2018) and 2 years rainy seasons (November 2016 and August and November 2018). The average rainfall during the rainy season (May to November) from 2016 to 2017 was $3466 \mathrm{~mm}$ (observed by DOA, Labutta township).

Leaching ratio $(\%)=\frac{\mathrm{EC}_{1: 5} \text { in dry season }-\mathrm{EC}_{1: 5 \text { in rainy season }}}{\mathrm{EC}_{1: 5 \text { in dry season }}} \times 100$

Soil salinity was highest near the river mouth in both dry and rainy seasons and gradually decreased away from the estuary. This indicates that the rice-growing areas in the delta are not completely protected against a periodic seawater intrusion even in rainy season. In the dry season, the $\mathrm{EC}_{1: 5}$ was $9.96 \pm 1.97 \mathrm{dS} \mathrm{m}^{-1}$ at maximum and $0.22 \pm 0.08$ $\mathrm{dS} \mathrm{m} \mathrm{m}^{-1}$ at minimum; in rainy season it was $2.67 \pm 0.28 \mathrm{dS}$ $\mathrm{m}^{-1}$ at maximum and $0.12 \pm 0.05 \mathrm{dS} \mathrm{m}^{-1}$ at minimum. This means that the soil EC on the topsoil can be regarded the maximum value as the upper limit in the dry season and the minimum value as the lower limit in the rainy season unless salts infiltrate the ground surface due to storm surge.

The reaching ratio, no matter how large or small of soil EC, was $60-80 \%$ up to $46 \mathrm{~km}$ from the estuary. These areas are in the range affected by seawater intrusion. In addition, the leaching ratio sharply declined at the upstream side of $46 \mathrm{~km}$ with the distance from Ywe river.

\section{Comparison of salinity indices and measured soil $\mathrm{EC}_{1: 5}$}

Table 4 shows the results of applied salinity indices (SI) in the study area. The calculation of SI in MODIS was only for the dry season in 2 years (March 2-6, 2017, and March $10-11,2018)$. In our study, salinity data for the rainy season were not considered, because the sky was covered with clouds and the MODIS time-series data were very noisy, and the range of $\mathrm{EC}_{1: 5}$ was narrow at $2.55 \mathrm{dS} \mathrm{m}^{-1}(0.12$ to $\left.2.67 \mathrm{dS} \mathrm{m}^{-1}\right)$. $\mathrm{SI}_{3}$ had the highest $R^{2}(=0.81)$, relatively 
Table 4 Applied salinity indices on the study area

\begin{tabular}{llll}
\hline Index & Equation & References & $\begin{array}{l}R^{2} \text { (polyno- } \\
\text { mial regres- } \\
\text { sion) }\end{array}$ \\
\hline Salinity Index 1 & $\mathrm{SI}_{1}=\sqrt{ }\left(B^{*} R\right)$ & Khan et al. (2005) & 0.3034 \\
Salinity Index 2 & $\mathrm{SI}_{2}=\sqrt{ }\left(G^{*} R\right)$ & Khan et al. (2005) & 0.7736 \\
Salinity Index 3 & $\mathrm{SI}_{3}=\sqrt{ }\left(G^{\wedge} 2+R^{\wedge} 2\right)$ & Douaoui et al. (2006) & 0.8089 \\
\hline
\end{tabular}

$B, G, R$ reflectance in the blue, green and red bands

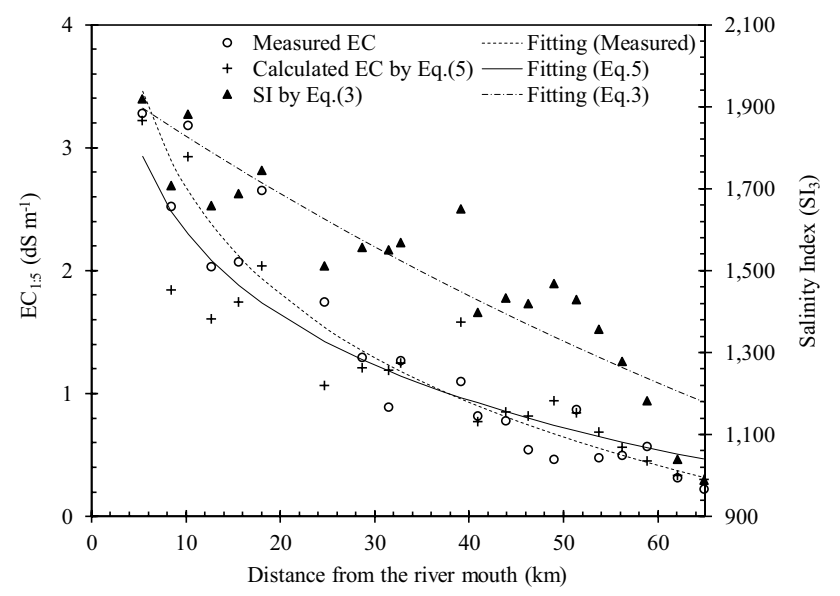

Fig. 5 Distribution of measured and calculated $\mathrm{EC}_{1: 5}$, and $\mathrm{SI}_{3}$ at distances from the river mouth in dry seasons

good correlation with measured soil EC. The relationship between $\mathrm{SI}_{3}$ and $\mathrm{EC}_{1: 5}$ was determined and a regression equation was obtained, as shown in Eq. (5). This equation limits to $0.07<\mathrm{SI}_{3}$.

$$
\begin{aligned}
\mathrm{EC}_{1: 5}\left(\mathrm{dS} \mathrm{m}{ }^{-1}\right)= & 2761.3\left(\mathrm{SI}_{3}\right)^{3}-807.24\left(\mathrm{SI}_{3}\right)^{2} \\
& +85.052\left(\mathrm{SI}_{3}\right)-2.886
\end{aligned}
$$

Figure 5 shows the distribution from the river mouth on the measured $\mathrm{EC}_{1: 5}$ for the dry season in two years average, the calculated $\mathrm{EC}_{1: 5}$ by Eq. (5), and $\mathrm{SI}_{3}$ calculated by Eq. (3). Although the $\mathrm{SI}_{3}$ range calculated by Eq. (3) of 1100-1600 has deviated from the measured $\mathrm{EC}_{1: 5}$, it confirmed and reproduced using Eq. (5). For each point, the calculated $\mathrm{EC}_{1: 5}$ by Eq. (5) corresponds well with measured $\mathrm{EC}_{1.5}$, and the root mean square error (RMSE) was $0.33 \mathrm{dS} \mathrm{m}^{-1}$. $\mathrm{SI}_{3}$ was highest near the river mouth in the dry season and gradually decreased away from estuary.

\section{Soil salinity seasonal pattern}

The calculated $\mathrm{EC}_{1: 5}$ using Eq. (5) and the smoothed line by the Lowess from 2004 to 2013 are shown in Fig. 6 . This figure shows from the Ywe river mouth to $23 \mathrm{~km}$ inland at the eight points average of calculated $\mathrm{EC}_{1: 5}$. The calculated SI was spread largely, caused by many clouds at the peak periods (May-June), and the MODIS time-series data were very noisy. The average of the measured $\mathrm{EC}_{1: 5}$
Fig. 6 Calculated $\mathrm{EC}_{1: 5}$ changes during 2004-2013 (from the river mouth to $23 \mathrm{~km}$ inland)

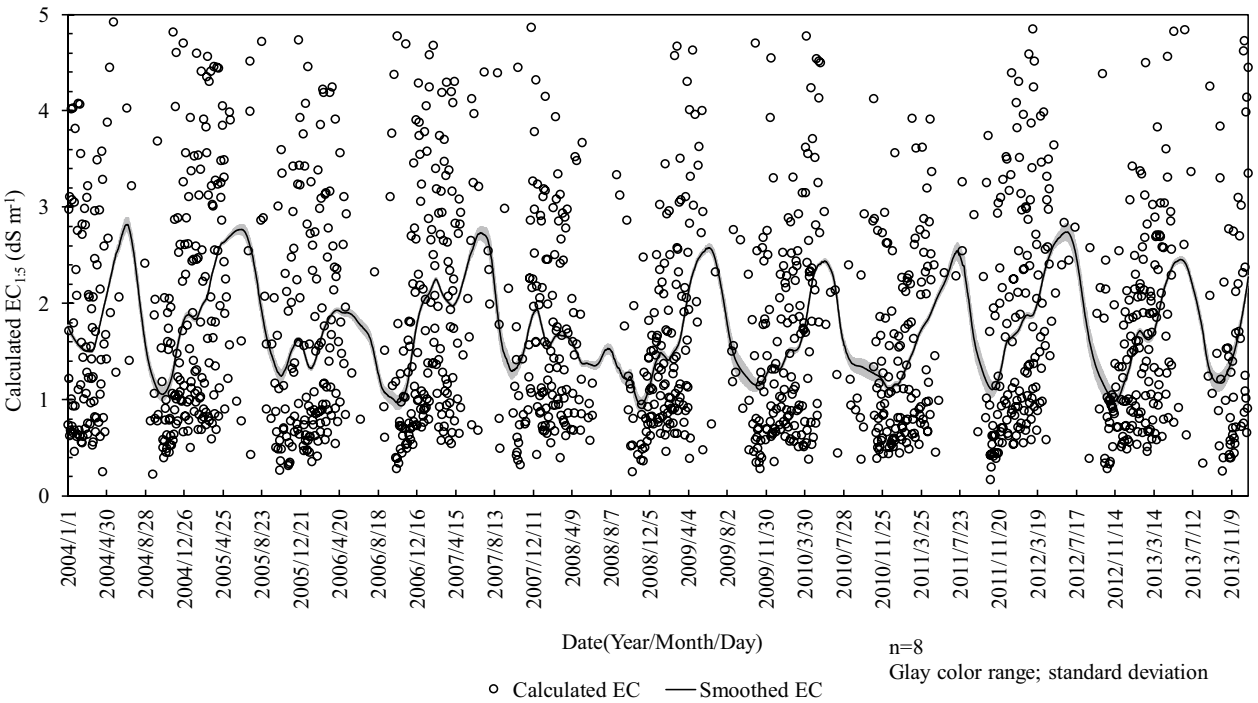


from the river mouth to $23 \mathrm{~km}$ inland shown in Fig. 4 in the dry season was $2.78 \mathrm{dS} \mathrm{m}^{-1}$. It was found from the result that the smoothed line moves upward during the dry season, the peak appeared at the end of May or early June (pre-monsoon season), and it tends to get lower in the rainy season.

The maximum value in the $\mathrm{EC}_{1: 5}$ seasonal change curve was used as the heading date; our study estimated the peak date of $\mathrm{EC}_{1: 5}$ from 2004 to 2013 and calculated the changes in $\mathrm{EC}_{1: 5}$ from 2009 to 2013, using the average of 2005 and $2007\left(2.75 \mathrm{dS} \mathrm{m}^{-1}\right)$ as the base year (Table 5). There was no tendency for soil EC to move up in the post-Nargis 2009 in dry seasons. From this result, although the calculation result is noisy, it was confirmed that the soil salinity in the dry season is almost constant even after about 10 years from the Nargis attacked.

\section{Discussions}

\section{Crop recovery period caused by cyclone Nargis}

We estimated the influence of recovery period by Cyclone Nargis attacked objectively through the MODIS NDVI timeseries data analysis from 2004 to 2013. The MODIS NDVI peak of Nargis landed year (2008) was estimated to reduce by $19.0 \%$ compared to the previous year, and it was estimated to take 3 years to the recovery (Fig. $3 a$ and Table 2). NDVI is identified as one of the prominent factors indicating the vegetation growth condition and the degree of vegetation cover of an area and it has obvious seasonal variations (Zhao et al. 2004). The relationship between the maximum NDVI value or the summation of the rice NDVI during the rice crop growing season and rice yield has been expressed by an exponential relationship (e.g. Ajith et al. 2017) or a linear relationship (e.g. Aboelghar et al. 2011). Based on the

Table 5 Peak date and its value of calculated EC and ratio of changes (from the river mouth to $23 \mathrm{~km}$ inland)

\begin{tabular}{llll}
\hline Year & Peak date & EC value & $\begin{array}{l}\text { Changes (\%) (average } \\
\text { of 2005 and 2007 as } \\
\text { base) }\end{array}$ \\
\hline 2004 & 30-May & 2.82 & \\
2005 & 2-Jun & 2.77 & \\
2006 & n/a & n/a & \\
2007 & 3-Jun & 2.73 & 0.0 \\
2008 & n/a & n/a & - \\
2009 & 29-May & 2.58 & -6.2 \\
2010 & 30-May & 2.44 & -11.3 \\
2011 & 5-Jun & 2.54 & -7.6 \\
2012 & 30-May & 2.74 & -0.4 \\
2013 & 4-Jun & 2.46 & -10.5 \\
\hline
\end{tabular}

government census statistics on the rice yield in the Labutta township, although there is no tendency to reduce the yield compared to the pre- and post-Nargis, besides, at the time of our studies we were unable to collect the reliable statistical data on rice yield compared to pre- and post-Nargis. May Phyoe Way (2015) found that after Nargis, yield of rice has reduced $19.25 \%$ in monsoon rice production through the literature reviews and interview with farmers, which was similar to our study result. May Phyoe Way (2015) estimated the reason for the yield reduction in monsoon rice that crop production was risky due to the influence of seawater flooding and pest problem such as rodent and crab, and farmers were not using the resources of land and labor effectively. Besides, UNEP (2009) reported that Nargis caused devastating damage to the environment. Cyclone Nargis destroyed 38,000 ha of natural and replanted mangroves, submerged over $63 \%$ of paddy fields, and damaged $43 \%$ of freshwater ponds. The impacts of the cyclones have been intensified by earlier damage to the environment, including deforestation and mangroves degradation, over-exploitation of natural resources such as fisheries, and soil erosion.

During our field survey in 2018, we have interviewed some farmers who live from the river mouth to $23 \mathrm{~km}$ inland. From those interviews, we got information that it took 3-5years to recover from the damage caused by Nargis (most often 3 years). In addition, these farmers described that rodent pest problem is still present.

In the field scale survey, Matsuda (2012) reported that although rice yields in some of the affected areas had recovered by the monsoon cropping season of 2009, yields in some of the survey areas along the coast were still less than half that before Nargis in 2010. Besides, Htwe et al. (2013) reported that massive rodent outbreaks occurred in the Ayeyarwady Delta in July 2009 due to the asynchronous planting using different varieties led to an extended harvest period, which provided a longer period of food availability for rodent. Our study using MODIS 250-m resolution does not adequately reflect the individual situation at the microlevel, such as at the village or farm level. However, in the delta, the storm surge caused by Cyclone Nargis destroyed embankments and entered into paddy fields. Under these conditions, conducting a field survey is difficult and risky. At the time of occurred of such an extreme event, our research approach was to understand the actual situation over a wide area using the remote sensing technique.

\section{Estimated factors on decline of NDVI peak from 2008 to 2010}

Based on our results, the decline factor in the MODIS NDVI peak in May 2008 was not salt effects caused by storm surge flooding of the cyclone (Fig. 6 and Table 5). 
In the dry season, little or no rainfall in the delta, and the downstream flow of freshwater becomes very low. Therefore, during the dry season period, soil salinity level became highest through evaporation in low land fields. According to our field survey results, salts accumulate in the dry season up to $46 \mathrm{~km}$ from the estuary due to saline water intrusion; however, $60-80 \%$ of salts are leached due to rain in the rainy season (Fig. 4). This event is constantly occurring. JICA (2011) reported that the cyclone struck the Ayeyarwady Delta on May 2-3, 2008, which was just before the wet season paddy cultivation started. It is considered that there was no agricultural crop plant growing on the surface of the paddy land; however, the surface soil was almost saturated by the considerable amount of rainfall. The rainfall water was stored for several months on the surface of the paddy field for the monsoon season, the leaching was accelerated, and the salt concentration has remarkably reduced. After landing in Cyclone Nargis, the rainfall in Labutta was $2451 \mathrm{~mm}$ during monsoon season (May-September) in 2008. Cyclone Nargis came at the end of the dry season (pre-monsoon); seawater intrusions were washed out by the following rainy season. As the salt leaching in the paddy field during monsoon season, FAO (1985) and Rasel et al. (2013) have reported that the rainfall during monsoon seasons reduce the surfaces soil salinity in the southwestern coastal zone of Bangladesh that is located about $800 \mathrm{~km}$ away from Ayeyarwady delta.

Therefore, it seems reasonable to conclude that the major factors on the decline of NDVI peak from 2008 to 2010 were attributed to the massive destruction to personal properties (home, crop, livestock, etc.) and main infrastructure (transportation, marketing, etc.). These are likely to be followed by the destruction of mangrove forests, seawater flooding, and pest outbreaks (rodents and crabs). The loss of assets and destruction of communication networks have resulted in the non-functioning of a majority of rural markets and limited supply of basic goods and services (FAO 2008).

\section{Conclusion}

Lower delta, like the Ayeyarwady Delta, has permanently or seasonally under influence of seawater intrusion; it is highly vulnerable to disasters such as storm surge caused by cyclones. In this study, it is the first time that satellite data analysis has objectively clarified the crop damage recovery period in the delta caused by Cyclone Nargis. In other words, we used daily composite data at a $250-\mathrm{m}$ resolution (MOD09GQ, collection 6) from 2004 to 2013, and we calculated NDVI and salinity index (SI) smoothed by locally weighted regression (Lowess). The MODIS NDVI peak value in 2008 was lower by $19.0 \%$ compared with 2007 data, and that the NDVI peak values declined for three straight years since May 2008 when Nargis struck.

In the dry season, salts accumulate up to $46 \mathrm{~km}$ from the estuary due to saline water intrusion; however, $60-80 \%$ of salts are leached due to rain in the rainy season. This event constantly occurs unless an extreme event occurs. However, we indicated a relationship between $\mathrm{EC}_{1: 5}$ values measured on the ground and the SI values extracted from corresponding pixels, and we evaluated salinity damage for pre- and post-Nargis (using SI equation) and showed that soil EC did not tend to move up in the dry season post-Nargis (2009), indicating that the decrease in NDVI values was not due to salinity damage. Although the calculated SI was spread largely, caused by many clouds during rainy seasons, and the MODIS time-series data were very noisy, it seems reasonable to conclude that the major factors on the decline of NDVI peak from 2008 to 2010 were attributed to the socio-economic factors such as massive destruction to personal properties (home, crop, livestock, etc.) and main infrastructure (transportation, marketing, etc.), and subsequent agroecological factors such as mangrove forests destruction, seawater flooding, and pest outbreaks (rodents and crabs).

In contrast, there are two cyclone seasons in the north Indian Ocean, namely the pre-monsoon (May) and the postmonsoon (October-November). The storm surge caused by the cyclone landed in the pre-monsoon will be leached out by rain in the rainy season, so salinity damage will not have a serious problem in the delta. In contrast, the cyclone in the post-monsoon, it will be estimated that salt will accumulate because no rainfall can be expected until the next year's rainy season. We need to clarify this hypothesis as a matter of further discussion.

Acknowledgements This paper describes a partial result of the collaborative research project, "Climate Change Measures in Agricultural Systems; Development of agricultural technologies for reducing greenhouse gas emissions and climate-related risks in developing countries," between Japan International Research Center for Agricultural Sciences (JIRCAS) and Yezin Agricultural University (YAU). The authors are especially grateful to the Department of Agriculture in Labutta for their cooperation and assistance in the field survey at Labutta.

Open Access This article is licensed under a Creative Commons Attribution 4.0 International License, which permits use, sharing, adaptation, distribution and reproduction in any medium or format, as long as you give appropriate credit to the original author(s) and the source, provide a link to the Creative Commons licence, and indicate if changes were made. The images or other third party material in this article are included in the article's Creative Commons licence, unless indicated otherwise in a credit line to the material. If material is not included in the article's Creative Commons licence and your intended use is not permitted by statutory regulation or exceeds the permitted use, you will need to obtain permission directly from the copyright holder. To view a copy of this licence, visit http://creativecommons.org/licenses/by/4.0/. 


\section{References}

Aboelghar M, Arafat S, Abo Yousef M, El-Shirbeny M, Naeem S, Massoud A, Saleh N (2011) Using SPOT data and leaf area index for rice yield estimation in Egyptian Nile delta. Egypt J Remote Sens Space Sci 14:81-89

Ajith K, Geethalakshmi V, Ragunath KP, Pazhanivelan S, Dheebakaran G (2017) Rice yield prediction using MODIS: NDVI (MOD13Q1) and land based observations. Int J Curr Microbiol Appl Sci 6(12):2277-2293. https://doi.org/10.20546/ijcmas.2017.612.263

Allbed A, Kumar L (2013) Soil salinity mapping and monitoring in arid and semi-arid regions using remote sensing technology: a review. Adv Remote Sens 2(4):373-385. https://doi.org/10.4236/ ars.2013.24040

Allbed A, Kumar L, Sinha P (2014) Mapping and modelling spatial variation in soil salinity in the Al Hassa Oasis based on remote sensing indicators and regression techniques. Remote Sens 6(2):1137-1157. https://doi.org/10.3390/rs6021137

Aung TT, Than MM, Ono K, Mochida Y (2011) Assessing the status of three mangrove species restored by the local community in the cyclone-affected area of the Ayeyarwady Delta, Myanmar. Wetl Ecol Manag 19(2):195-208

Cleveland WS, Devlin SJ (1988) Locally weighted regression: an approach to regression analysis by local fitting. J Am Stat Assoc 83(403):596-610. https://doi.org/10.2307/2289282

Crop Science Society of Japan (2012). http://www.cropscience.jp/earth quake/kondo.html. Accessed 27 Apr 2020 (in Japanese)

Douaoui AEK, Kicolas H, Walter C (2006) Detecting salinity hazards within a semiarid context by means of combining soil and remote-sensing data. Geoderma 134(1):217-230. https://doi. org/10.1016/j.geoderma.2005.10.009

Driel WF, Nauta TA (2014) Vulnerability and resilience assessment of the Ayeyarwady Delta in Myanmar. Full assessment phase. Delta Alliance report no. 10. Bay of Bengal Large Marine Ecosystem (BOBLME) Project, Global Water Partnership (GWP) and Delta Alliance, Delft-Wageningen, The Netherlands, pp 58-84

Dutta D, Das PK, Paul S, Sharma JR, Dadhwal VK (2015) Assessment of ecological disturbance in the mangrove forest of Sundarbans caused by cyclones using MODIS time-series data (2001-2011). Nat Hazards 79(2):775-790

FAO (1985) Report on Tidal area study, fisheries resources survey system (FAO/UNDP-BGD/79/015). http://www.fao.org/docrep/ field/003/AC352E/AC352E00.htm. Accessed 31 Jan 2018

FAO (2008) Emergency and rehabilitation programme: needs assessment for the Cyclone Nargis affected areas, agriculture (crops, livestock, fisheries, forestry), $\mathrm{p} 87$

Fee L, Gibert M, Bartlett R, Capizzi P, Horton R, Lesk C (2017) Climate change vulnerability assessment of Labutta Township, Ayeyarwady Region, Myanmar, 2016-2050, UN-Habitat Myanmar

Fritz HM, Blount C, Thwin S, Thu MK, Chan N (2009) Cyclone Nargis storm surge flooding in Myanmar's Ayeyarwady River Delta, Indian Ocean Tropical Cyclones and Climate Change, pp 295-303

Glenn EP, Huete AR, Nagler PL, Nelson SG (2008) Relationship between remotely-sensed vegetation indices, canopy attributes and plant physiological processes: what vegetation indices can and cannot tell us about the landscape. Sensor 8:2136-2160

Goto K, Goto T, Nmor JC, Minematsu K, Gotoh K (2015) Evaluating salinity damage to crops through satellite data analysis: application to typhoon affected areas of southern Japan. Nat Hazards 75(3):2815-2828

Hmimina G, Dufrene E, Pontailler JY, Delpierre N, Aubinet M, Caquet B, Grandcourt A, Burban B, Flechard C, Granier A, Gross P, Heinesch B, Longdoz B, Moureaux C, Ourcival JM, Rambal S, Saint Andre LS, Soudani K (2013) Evaluation of the potential of
MODIS satellite data to predict vegetation phenology in different biomes: an investigation using ground-based NDVI measurements. Remote Sens Environ 132:145-158

Htwe NM, Singleton GR, Nelson A (2013) Can rodent outbreaks be driven by major climatic events? Evidence from Cyclone Nargis in the Ayeyawady Delta, Myanmar. Pest Manag Sci 69:378-385. https://doi.org/10.1002/ps.3292

Japan International Cooperation Agency (JICA) (2011) The project for preservation of farming area for urgent rehabilitation of agricultural production and rural life in areas affected by Cyclone Nargis final report, main report, $\mathrm{p} 61$

Karlsen SR, Tolvanen A, Kubin E, Poikolainen J, Hogda KA, Johansen B, Danks FS, Aspholm P, Wielgolaski FE, Makarova O (2008) MODIS-NDVI-based mapping of the length of the growing season in northern Fennoscandia. Int J Appl Earth Obs Geoinf 10(3):253-266

Kerr JT, Ostrovsky M (2003) From space to species: ecological applications for remote sensing. Trends Ecol Evol 18(6):299-305

Khan NM, Rastoskuev VV, Sato T, Shizawa S (2005) Assessment of hydrosaline land degradation by using a simple approach of remote sensing indicators. Agric Water Manag 77(1-3):96-109. https://doi.org/10.1016/j.agwat.2004.09.038

Konda VGRK, Chejarla VR, Mandla VR, Voleti V, Chokkavarapu N (2018) Vegetation damage assessment due to Hudhud cyclone based on NDVI using Landsat-8 satellite imagery. Arab J Geosci 11:35. https://doi.org/10.1007/s12517-017-3371-8

Matsuda M (2009) Dynamics of rice production development in Myanmar: growth centers, technological changes, and driving forces. Trop Agric Dev 53(1):14-27

Matsuda M (2012) Impact of Cyclone Nargis on rice production and the process of restoration in the Ayeyarwady Delta, Myanmar: three years after the disaster. J Trop Agric Dev 5(2):88-96 (in Japanese)

May Phyoe Way (2015) Assessment of socioeconomic situation and analysis of farming systems in the cyclone affected region case study (Bogale, Myanmar). J Agric Sci Technol CienciAgro $1: 21-28$

Ministry of Agriculture and Irrigation in Myanmar (MOAI) (2015) Myanmar rice sector development strategy, pp 23-24

Myanmar Environment Institute (2017) Labutta township environmental assessment 2017 final report, p 57

Rasel HM, Hasan MR, Ahmed B, Miah MSU (2013) Investigation of soil and water salinity, its effect on crop production and adaptation strategy. Int J Water Resour Environ Eng 5(8):475-481

Seinn Seinn MU, Ahmad MM, Thapa GB, Shrestha RP (2015) Farmers' adaptation to rainfall variability and salinity through agronomic practices in lower Ayeyarwady Delta, Myanmar. Earth Sci Clim Change 6:258. https://doi.org/10.4172/2157-7617.1000258

Shibayama M, Sakamoto T, Takada E, Inoue A, Morita K, Yamaguchi T, Takahashi W, Kimura A (2012) Estimating rice leaf greenness (SPAD) using fixed-point continuous observations of visible red and near infrared narrow-band digital images. Plant Prod Sci 15(4):293-309. https://doi.org/10.1626/pps.15.293

United Nations Environment Programme (UNEP) (2009) Learning from Cyclone Nargis: a case study, investing in the environment for livelihoods and disaster risk reduction. https://wedocs.unep. org. Accessed 14 Sep 2020

Vermote EF, Roger JC, Ray JP (2015) MODIS Surface Reflectance User's Guide Collection 6, MODIS Land Surface Reflectance Science Computing Facility. https://modis-land.gsfc.nasa.gov. Accessed 17 June 2018

Zhao B, Liu C, Wang J (2004) Spatial and temporal change of MODISNDVI in Xilinguole Grassland. Grassl China 26(1):1-8 